\title{
OSSEOUS METAPLASIA: A LATE PATHOLOGICAL FINDING WITHIN THE SCAR TISSUE FORMED FOLLOWING SPINAL INJURY
}

By Christine M. L. Smith, B.A., M.B., Ch.B., ${ }^{1}$ A. A. Jefferson, M.D., F.R.C.S., ${ }^{2}$ W. R. Timperley, M.A., D.M., F.R.C.Path. ${ }^{3}$ and N. Watson, M.B., D.Ph. ${ }^{4}$

${ }^{1}$ Senior Registrar, Department of Neuropathology, ${ }^{2}$ Consultant Neurosurgeon, Department of Neurosurgery, ${ }^{3}$ Consultant Neuropathologist, Department of Neuropathology, Royal Hallamshire Hospital, Sheffield $S_{I O} 2 \mathcal{F F},{ }^{4}$ Consultant in Spinal Injuries, Lodge Moor Hospital, Sheffield

Summary. A total of 17 cordectomy specimens and 22 post mortem specimens from long survival spinal injury patients were reviewed. Bone formation within the scar tissue was found in 28.5 per cent of cases. The evidence suggests that this is metaplastic bone formed within dense collagenous scar tissue. The significance of this osseous metaplasia is discussed.

Key words: Spinal injuries; Ossification-intradural intramedullary and nerve root; Metaplasia; Nerve regeneration.

\section{Introduction}

The PATHOLOGICAL CHANGES in the spinal cord following traumatic injury have been the subject of several experimental and post mortem studies in which both acute and chronic changes have been well documented (Wolman, I964; Hughes, I974, I966, I976; Wagner et al., I978; Balantine, I978).

The purpose of this paper is to report a further late pathological finding which we have observed within the scar tissue in a significant number of traumatised spinal cords.

Heterotopic bone formation in patients with paraplegia following spinal injury has been the subject of several reports (Hardy \& Dickson, I963; Miller \& O'Neill, I949; Damanski, I96I). It has been described in several sites, always below the level of the central neurological lesion; these sites include the soft tissues surrounding joints, muscle and in association with decubitus ulcers. It has been estimated that it occurs in between I 5 per cent and 50 per cent of paraplegic patients. New bone formation occurring in relation to the actual site of cord injury does not however appear to have been previously described.

\section{Materials and Methods}

The spinal cords of 39 cases of traumatic paraplegia, 17 of which were cordectomies undertaken for intractable pain, and $\mathbf{2 2}$ were autopsy specimens, provided the material for our investigation. After fixation, a series of sections were taken through the damaged portions of the cord and examined lising light-microscopy. The sections were routinely stained with haematoxylin and eosin, Holmes silver stain for axons, and solochrome 
cyanin for myelin sheaths. In all cases the initial injury is expressed in terms of the vertebrae involved. The histological findings, where a level is given, relate to the spinal cord segment.

\section{Results}

Evidence of bone formation within the scar tissue of the traumatised spinal cords was found in five of the cordectomy specimens and six of the autopsy specimens, an incidence of $29 \cdot 4$ per cent and $27 \cdot 3$ per cent respectively. The time elapsing after injury ranged from 5-I 8 years for the cordectomy specimens and from 8-25 years for the autopsy specimens. With the exception of one case which involved thoracic vertebrae 5 and 6 , the cases involved the lower thoracic and lumbar vertebrae.

The relevant findings in the cases in which cicatrical bone formation was present are summarised below.

\section{Cordectomy Specimens}

Case I: F.C., Male, Age 23.

Compression fracture LVI and dislocation of DVI 2 on LVI. Treated by open reduction and plating. Cordectomy after 5 years. The fibrous scar tissue within the cauda equina contained irregular spicules of lamellar bone showing cement lines and containing osteocytes. Marrow spaces were filled with loose fibrous tissue.

Case 2: D.L.-W., Female Age 40

Prolapsed lumbar disc. Cordectomy after I 3 years. Extensive sheets of lamellar bone present in the dense fibrous scar tissue encasing the gliotic remnant of the sacral cord. Haversian systems present. Marrow spaces filled with haemopoietic marrow.

Case 3: B.T., Male, Age 37.

Fracture dislocation DVI2 on LVI. Treated by open reduction and internal fixation. Cordectomy after i 8 years. Scar tissue surrounding the cauda equina nerve roots contained extensive lamellar bone. Prominent rows of osteoblasts and an occasional osteoclast are present. Marrow spaces contain adipose, loose connective tissue and bundles of nerve fibres. Haversian systems present.

Case 4: D.B., Male, Age 24.

Fracture dislocation DVI I on DVI2. Treated by manipulation. Cordectomy after 6 years. Spicules of lamellar bone embedded in fibrous and gliotic cord remnants. Marrow spaces contain adipose and fine connective tissue.

Case 5: L.B., Male, Age 39.

Fracture dislocation LVI on LV2. Treated by open reduction and plating. Cordectomy after 8 years. At level $\mathrm{L}_{4} / 5$ the thickened meninges contain 
spicules of lamellar bone closely associated with bundles of regenerating nerve fibres.

\section{Autopsy Specimens}

Case I: E.T., Male, Age 65.

Fracture dislocation DVI2 on LVI. Treated by open reduction and plating. Survival 8 years. Died in renal failure. Fibrous scar tissue in and around the lower part of the damaged cord contained abundant lamellar bone with Haversian systems, and interstices containing haemopoietic marrow. Osteoid seams present. Adjacent areas show foci of calcification.

Case 2: R.S., Male, Age 64.

Fracture dislocation D5 on DV6. Conservative treatment. Survived I6 years. Died of carcinoma of stomach. At segmental level $\mathrm{D}_{5}$ the cord was entirely replaced by fibrous tissue containing extensive sheets of lamellar bone. Metastatic carcinoma also present.

Case 3: B.A., Male, Age 7 I.

Fracture dislocation DVI i on DVi2. Conservative management. Survival 24 years. Death from acute peritonitis following perforation of chronic duodenal ulcer. Fibrous and gliotic scar tissue at the lumbar level contains extensive lamellar bone. Marrow spaces contain haemopoietic marrow and Haversian systems are well formed.

Case 4: G.S., Male, Age 56.

Fracture dislocation DVI2 on LVI. Open reduction and plating. Survived 25 years. Died in renal failure. Spicules of lamellar bone in thickened and fibrotic meninges around damaged cord. Small foci of calcification scattered throughout the scar tissue.

Case 5: W.W., Male, Age 58.

Fracture LVI. Traumatic spondylolisthesis $\mathrm{LV}_{3}$ on $\mathrm{LV}_{4}$. Treated conservatively. Survived 12 years. Death due to renal amyloidosis. Active formation of lamellar bone occurring within the scarred meninges around the lumbar cord. Marrow spaces contain loose areollar tissue and wide osteoid seams are apparent.

Case 6: R.M., Male, Age 56.

Fracture dislocation DVI I on DVi2. Open reduction and plating. Survived 20 years. Death due to carcinoma of urinary bladder. Fine spicules of lamellar bone in the extradural tissue to one lateral aspect of the damaged lumbar cord. Active osteoblasts present. Marrow spaces filled with adipose and loose connective tissue.

In all the cases the spicules of bone consisted of lamellar bone showing an orientated arrangement of collagen fibres when examined with a polar- 


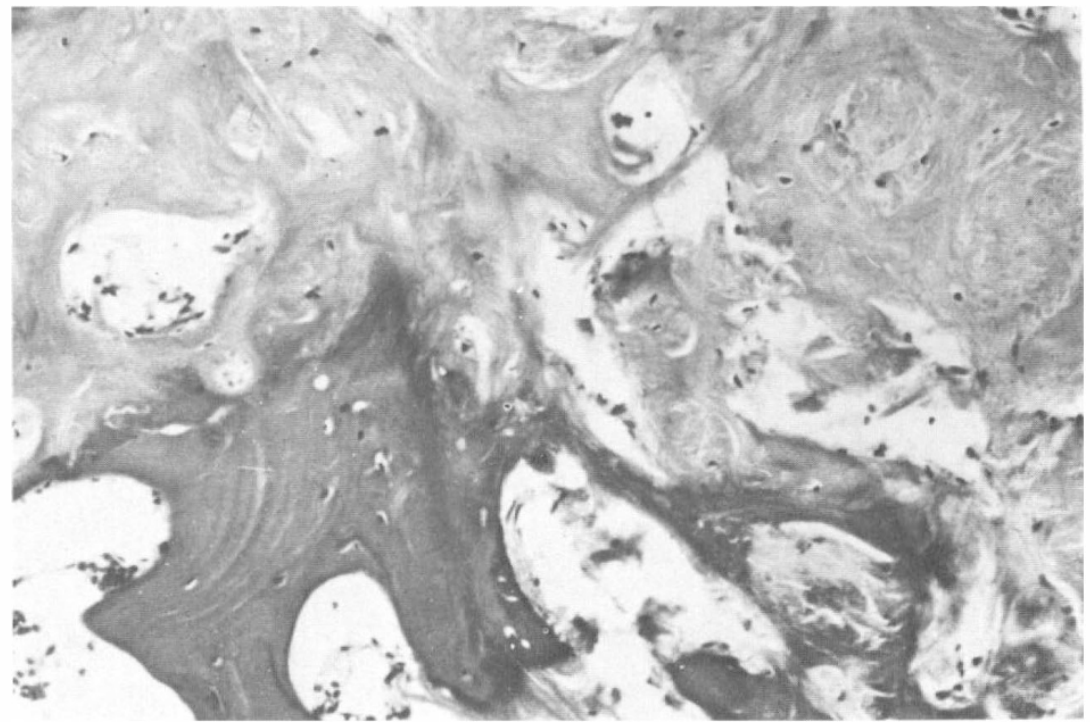

FIG. I

Photomicrograph showing an area of new bone formation within the dense fibrous scar tissue found following spinal injury. (Haematoxylin and eosin, $\times 560$ ).
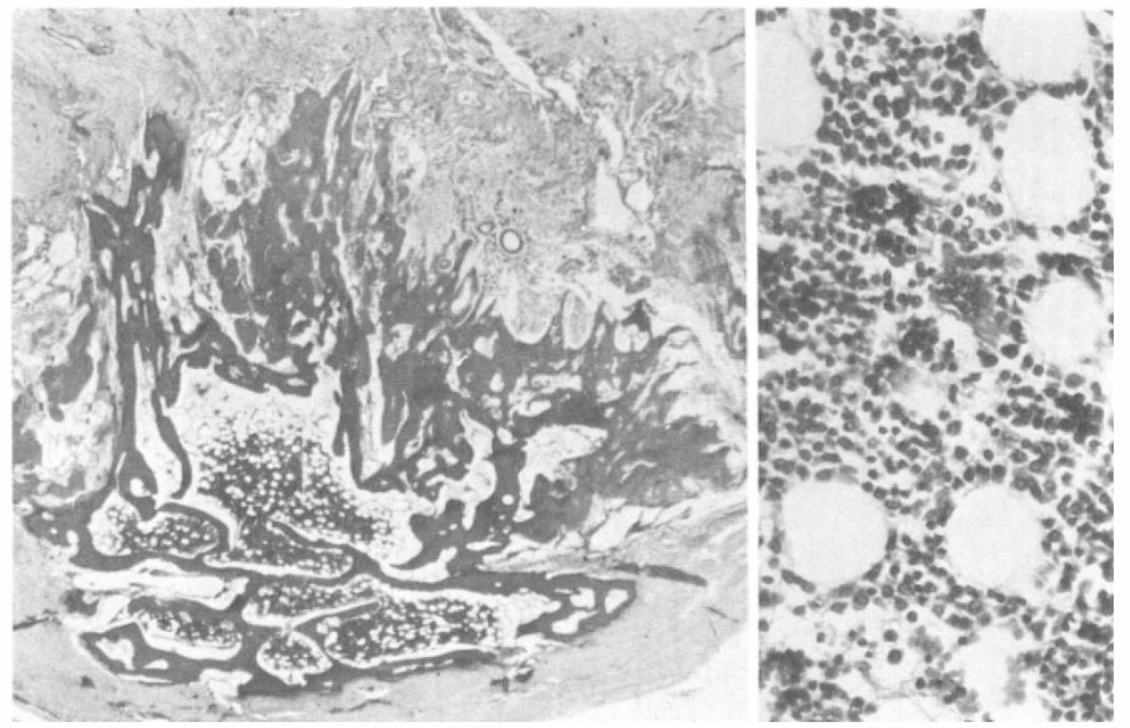

FIG. $2 \mathrm{~A}$ and B

(A) Photomicrograph showing haemopoietic marrow within the interstices of cicatrical bone. The bone is surrounded by dense fibrous scar tissue (haematoxylin and eosin $\times 40$ ). (B) A high power inset shows the haemopoietic marrow with several megakaryocytes. 


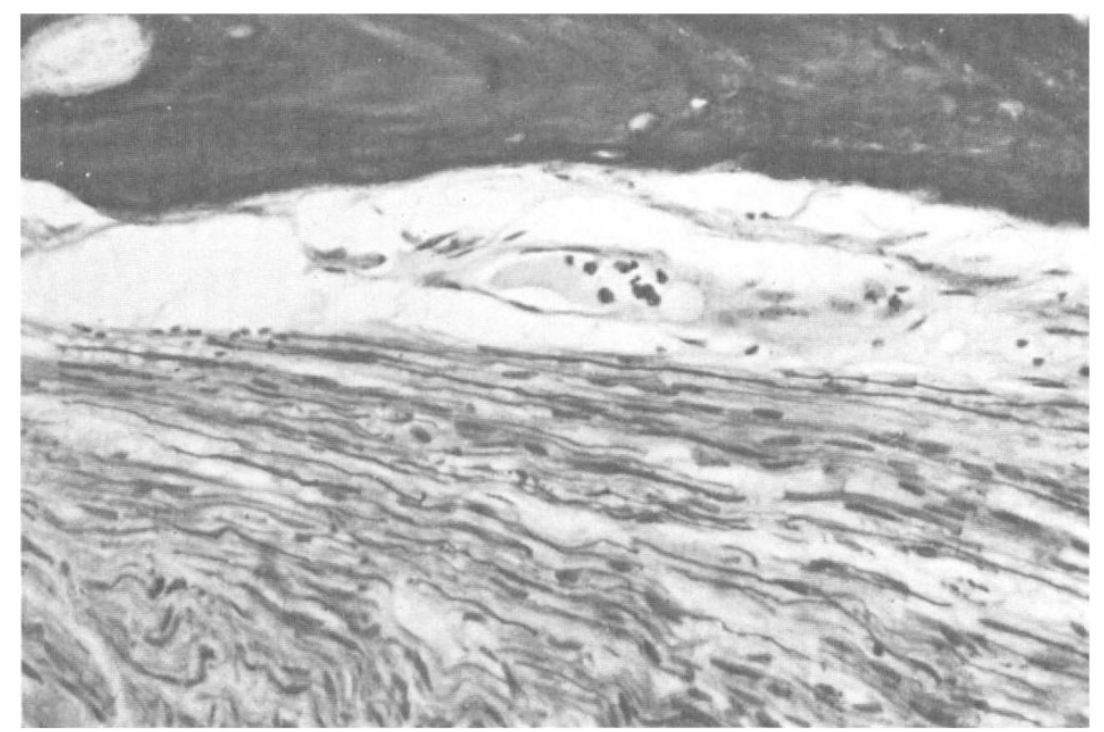

FIG. 3

Photomicrograph showing parallel bundles of regenerating nerve fibres within the marrow spaces of cicatrical bone. (Holmes' silver impregnation technique, $\times 560$ ).

ising microscope. The bone was surrounded by dense fibrous or glial scar tissue with evidence of gradual change from one to the other (Fig. I). All areas of bone contained identifiable osteocytes and cement lines. The majority of cases showed evidence of Haversian system formation and osteoid seams of variable width. Rows of osteoblasts were fairly common but osteoclasts on the other hand were rarely seen. The interstices of the bone were generally filled with loose areollar, fibrous or adipose tissue but in three cases haemopoietic marrow (Fig. 2) was present. In two cases bundles of regenerating nerve fibres had penetrated the marrow spaces and were growing in parallel bundles through the marrow spaces (Fig. 3).

The siting of the bone formation varied and was clearly related to the site of scar tissue formation. Bone was identified within the damaged cord itself, in relation to the meninges and in one case within the extradural tissue.

Bone formation appeared unrelated to the mechanism of the original injury or to the subsequent method of management. There was in the majority of cases no radiological evidence of displaced bone fragments and in only one case was the dura breached at operation for the open reduction of the fracture dislocation.

\section{Discussion}

In addition to the pathological findings previously documented and discussed in both clinical and experimental situations, we have noted bone formation within the scar tissue occurring in a relatively high proportion of the cases examined, that is $28 \cdot 2$ per cent of our series. 
One possible theory as to the origin of the bone is that it arose from fragments implanted at the time of injury. However, clinical and radiological evidence at the time of injury does not support this. In addition, it has been observed that both the spinal dura mater and arachnoid are very strong connective tissue membranes and in many spinal injuries in which one or more segments of spinal cord are destroyed and a complete transection is clinically evident, the dura and arachnoid remain intact (Hughes, I974). Bone was present within the intradural tissue in a number of cases in which the dura was observed directly at operation to be intact.

The extraosseous formation of bone and cartilage has frequently been observed in scars, chronic inflammatory and degenerative lesions, sclerotic arteries, muscle and tumours. Ossification within scar tissue appears to be most frequently described in relation to upper abdominal scars in or near the linea alba (Roth et al., I963). In addition we report its relatively frequent occurence in the scar tissue of the cord following spinal injury.

Metaplasia may be defined as a reversible change in which one adult cell type is replaced by another cell type and is known to occur in both epithelial and mesenchymal cells (Robbins \& Cottran, I979; Walter \& Israel, I979). Theories of mesenchymal metaplasia do not envisage the direct transfer of one adult cell type into another adult cell type, but rather the conditioning of less differentiated 'reserve' cells to differentiate along divergant lines (Scott \& Flesine, I982). Bone, whether woven or lamellar is formed by osteoblasts which manufacture collagen fibres as well as oseomucin and these cells contain alkaline phosphatase. It is considered that scattered throughout all adult tissues are primitive connective tissue elements or 'stem' cells which are capable of proliferation as the necessity arises. These so-called 'stem' or 'reserve' cells are capable of producing a variety of mature mesenchymal cells which include osteoblasts. These primitive mesenchymal cells appear to proliferate alongside capillary ingrowths which occur into areas of inflammation and traumatic damage such as occur following an acute spinal injury.

The intraosseous formation of calcified bone is dependent on a multitude of factors (Anderson, I980) which include the conditions of the $\mathrm{pH}$, calcium, phosphate and citrate ion concentrations, vitamin $\mathrm{D}$ concentration, oxygen tension, the presence of enzymes, the state of the organic bone matrix, as well as the possible presence of some inducer agents. The role of these factors has not been fully studied in extraosseous bone formation but any traumatic tissue damage will cause haemorrhage, necrosis and subsequent regeneration. All these factors might affect changes in calcium and phosphate ion concentration, $\mathrm{pH}$, oxygen tension and the concentration of enzymes present, resulting in calcification of the osteoid laid down by the newly formed osteoblasts.

It has been suggested that in cases of abnormal tissue calcification the formation of bone is dependent upon the rate of organisation of the deposit (Eisenstein et al., I960). If the organisation is rapid the calcium deposit is completely absorbed. A slow rate on the other hand will favour the retention of the inorganic calcium deposited. With optimum conditions however, the mesenchymal cells accompanying the in-growing capillaries become osteoblasts and bone formation occurs. Deposition of calcium salts has been described in experimental spinal cord trauma with selective localisation in axons (Balantine \& Spector, I977; Wolman, I966), calcifica- 
tion being abundant after an interval of I week and less evident at I month, in parallel with the density of macrophages noted. Clearly in some cases conditions could occur where the presence of metastatic osteoblasts and optimum calcification conditions could coincide and lead to the deposition of cicatrical bone. The fact that metaplastic bone does not form in cerebral scar tissue suggests that local factors, possibly inducers, play an important part.

The function and significance of this metaplastic bone formation should be considered. It has been suggested that epithelial metaplasia represents an adaptive response in which cells sensitive to stress are replaced by other cell types better able to withstand an adverse environment (Robbins \& Cottran, I979). In the case of mesenchymal cells however, this is much less obviously an adaptive response, although in the case of cicatrical osseous metaplasia it could be that bone formation conferred increased strength in the resultant scarred area.

A considerable amount of attention has been directed towards the existence and significance of axon regeneration within the spinal cord. Two types of neurone appear to have the ability to show regeneration: the anterior horn cell and the posterior spinal ganglion neurones, both of whose processes possess Schwann cell sheaths. Failure of the regenerating fibres to make any useful connections may in part be due to the presence of dense connective scar tissue within the damaged area (Wolman, I966; Hughes \& Brownell, I963). It is of interest, however, that in the two cases in which large numbers of regenerating axons were seen within the marrow spaces of the metaplastic bone, these myelinated axons were growing in orderly parallel rows. This suggests that provided regenerating axons can be guided in their direction of growth, at least some useful function could be re-established.

\section{RÉSUMÉ}

On a examiné un total de 17 spécimens de cordectomie et 22 autres spécimens après autopsie de patients qui avaient survécu longtemps à une lésion de la colonne vertébrale. Une formation osseuse dans le tissue cicatriciel a été observée dans $28 \cdot 2$ per cent des cas. L'évidence suggère que nous sommes en présence d'os métaplastique formé à l'intérieur du tissue cicatriciel dense collagéneux. On duscutera la significance de cette méplasie osseuse.

\section{ZUSAMMENFASSUNG}

Es wurde eine Gesamtzahl von 17 Chordektomiefallen und 22 postmortem Fällen von Langzeitüberlebenden nach spinalen Verletzungen beobachtet. In $28.8 \%$ der Fälle wurde eine Knochenbildung innerhalb des Narbengewebes festgestellt. Diese Beobachtung lässt vermuten, dass es sich dabei um metaplastische Knockensubstanz handelt, welche sich in dichtem, kollagenalem Narbengewebe bildet. Die Bedeutung dieser knöchernen Metaplasia wurde diskutiert.

\section{REFERENCES}

Anderson, M. C. (1980). Calcification processes. Pathol. Annual, Part 2, 45-75.

Balantine, J. D. (1978). Pathology of experimental spinal cord trauma. Lab. Invest., 39, 236-253.

Balantine, J. D. \& Spector, M. (I977). Calcification of axons in experimental spinal cord trauma. Ann. Neurol., 2, 520-528. 
Damanski, M. (196I). Heterotopic ossification in paraplegia. f. Bone ft. Surg., 43, 286-299.

Eisenstein, R., Frueheart, R. E., \& Hass, G. M. (i960). In: Pathogenesis of Abnormal Tissue Calcification. Calcification in Biological Systems, pp. 28I-305. Sognmaes, R. F. Amer. Assoc. for the Advancement of Science, Washington, DC.

HARDY, A. G., \& Dickson, J. W. (1963). Pathological ossification in traumatic paraplegia. f. Bone ft. Surg., 45, 76-87.

Hughes, J. T. (1966). Pathology of the Spinal Cord, pp. 9i-IOI. Lloyd-Luke, London.

Hughes, J. T. (1974). Pathology of the spinal cord damage in spinal injuries. In: Brock's Injuries of the Brain and Spinal Cord, 5th ed., pp. 668-687, Feiring, Springer, New York.

Hughes, J. T. (1976). Traumatic lesions of the spinal cord. In: Greenfield's Neuropathology, 3rd ed., pp. 664-668. Blackwood, Arnold.

Hughes, J. T. \& BRownell, B. (1963). Aberrant nerve fibres within the spinal cord. F. Neurol. Neurosurg. Psychiat., 26, 528-534.

Miller, L.F. \& O’Neill, C. J. (I949). Myositis ossificans in paraplegics. f. Bone ft. Surg., 31, 283-294.

Robbins, L. \& CotTran, R. S. (1979). Pathologic Basis of Disease, pp. I2-2I. Saunders, Philadelphia.

Roth, S. I., Stowell, R. W. \& Helwig, E. G. (1963). Cutaneous calcification. Arch. Pathol., 76, 44-54.

ScotT, R. E. \& FlEsine, D. L. (1982). Cell cycle models for the aberrant coupling of growth arrest and differentiation in hyperplasia, metaplasia and neoplasia. Amer. $\mathcal{F}$. Pathol., 107, 342-348.

Wagner, F. C., VAN Gilder, J. C., \& Dohrmann, G. J. (1978). Pathological changes from acute to chronic in experimental spinal cord trauma. F. Neurosurg., 48, 92-98.

Walter, J. B., \& ISRAel, M. S. (I979). General Pathology, pp. 303-306. Churchill Livingstone.

Wolman, L. (1964). The neuropathology of traumatic paraplegia-a critical historical review. Paraplegia, 1, 233-25I.

Wolman, L. (1966). Axon regeneration after spinal injury. Paraplegia, 4, I75-I 88. 